\title{
DO HUMMINGBIRDS FOLLOW SAPSUCKERS TO FOOD SOURCES?
}

RICHARD W. KNAPTON, Department of Biological Sciences, Brock University, St. Catharines, Ontario, L2S 3A1 RALPH V. CARTAR and JOHN D. REYNOLDS, Department of Biology, Queen's University, Kingston, Ontario.

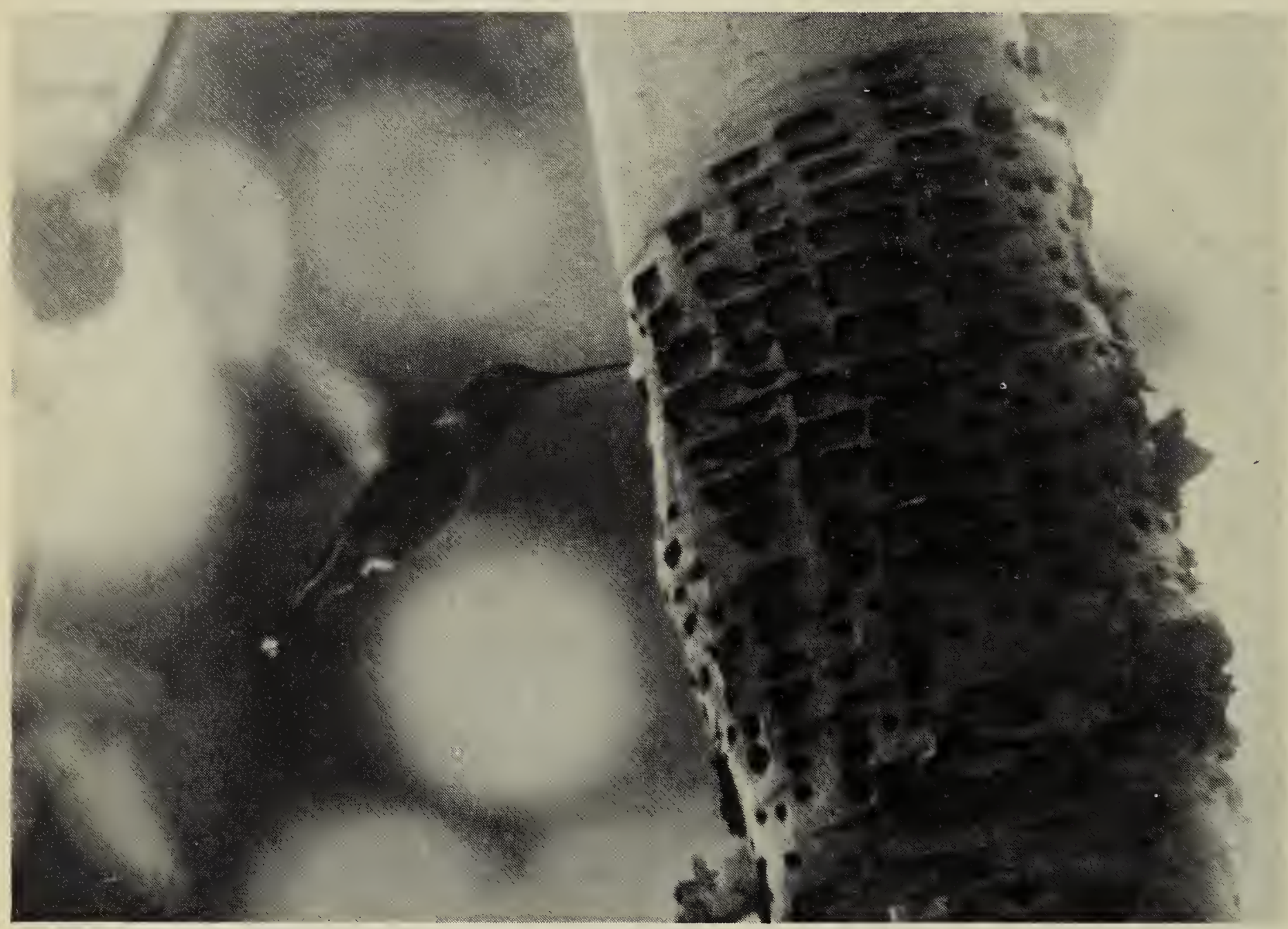

Hummingbird feeding at sapsucker drills

Anonymous

Feeding on tree sap by hummingbirds has been widely reported, especially at holes drilled by sapsuckers.' This is especially important for the Ruby-throated Hummingbird in its northern distribution in Canada; the hummingbird often arrives in spring before food plants have appeared, and it occurs during the breeding season in habitats in which food plants may be scarce or unavailable. ${ }^{2}$ The primary source of food is most likely sucrose in sap from trees drilled by sapsuckers, ${ }^{2}$ and indeed some Rubythroated Hummingbirds are thought to specialize on tree sap and rarely take flower nectar. ${ }^{3}$ Such individuals could locate food sources by searching for drilled holes or by following sapsuckers to feeding sites. In this note, we report instances of hummingbirds following and maintaining close association with sapsuckers. 
We made the observations at Algonquin Provincial Park, Nipissing District, Ontario, in 1980. On 30 May, a female Rubythroated Hummingbird was seen flying across a clearing close behind a male Yellow-bellied Sapsucker at 8:13 p.m. The sapsucker landed about $1 \mathrm{~m}$ above ground on a White Birch, and moved up the birch for about $2 \mathrm{~m}$. The hummingbird hovered near the sapsucker for the first $1 \mathrm{~m}$ of ascent, then perched for the rest of the ascent, keeping about $0.5 \mathrm{~m}$ away at all times. The sapsucker, with the hummingbird in close attendance, next flew $20 \mathrm{~m}$ to a White Spruce and landed $2 \mathrm{~m}$ above ground. The woodpecker spent about a minute working its way about $4 \mathrm{~m}$ up the trunk of the spruce, then flew $5 \mathrm{~m}$ to another White Spruce, alighting $6 \mathrm{~m}$ above ground. It progressed $10 \mathrm{~m}$ up the trunk in about 3 minutes, then left the tree and flew out of sight. The hummingbird kept within $0.5 \mathrm{~m}$ of the sapsucker at all times, whether the sapsucker was foraging or in flight. While the sapsucker foraged on the spruces, the hummingbird flew from perch to perch, zigzagging from one side of the tree to the other, always maintaining close attendance. The two birds flew out of sight together.

A similar event was observed $10 \mathrm{~km}$ away at 12:00 p.m. on 7 June. A female Rubythroated Hummingbird followed a sapsucker closely for about 3 minutes as the sapsucker foraged on, and flew between, several Sugar Maples. The hummingbird perched on twigs close to the sapsucker while the latter was foraging on the tree trunks, immediately left its perch when the sapsucker left the tree, and flew close alongside the sapsucker when the latter was in flight.

The sapsuckers were not observed to drill new holes, and hence we recorded no feeding by the hummingbirds. However, it seems highly plausible that in each case the hummingbirds were indeed following sapsuckers to locate feeding sites.

\section{Acknowledgments}

We thank Bob Montgomerie for discussions and references, Bob Nero for comments on an earlier draft, and the Ontario Ministry of Natural Resources for providing facilities at Sasajewan Lake, Algonquin Provincial Park.

' FOSTER, W.L. and J. TATE, Jr. 1966 The actions and coactions of animals at sapsucker trees. Living Bird 5:87-113.

2 MILLER, R.S. and R.W. NERO 1983 Hummingbird - sapsucker associations in northern climates. Can. J. Zool. 61:1540-1546.

${ }^{3}$ SOUTHWICK, E.E. and A.K. SOUTHWICK 1980 Energetics of feeding on tree sap by Rubythroated Hummingbirds in Michigan. Am. Midland Nat. 104:328-334.

\section{SNHS WHOOPING CRANE TOURS - 1985}

One day tour departs Saskatoon on 28 September and 5 October. The cost is $\$ 65$. Register by writing SNHS, Box 1784, Saskatoon, Saskatchewan. S7K 3 S1 